\title{
GNA11 Gene Mutation Negative
}

National Cancer Institute

\section{Source}

National Cancer Institute. GNA11 Gene Mutation Negative. NCI Thesaurus. Code C160367.

A genetic finding indicating that GNA11 gene mutations have not been detected in a sample. 